\title{
Pelatihan Komputer Dasar Berbasis Aplikasi Microsoft Office bagi Siswa SMK Negeri 3 Merauke Provinsi Papua
}

\author{
Wahyuniar $^{1^{*}}$, Desy Kumala Sari ${ }^{2}$, Rezky Uspayanti ${ }^{3}$ \\ ${ }^{1 *}$ Pendidikan Bahasa dan Sastra Indonesia, Universitas Musamus \\ ${ }^{2}$ Pendidikan Fisika, Universitas Musamus \\ ${ }^{3}$ Pendidikan Bahasa Inggris, Universitas Musamus \\ *Corresponding Author. Email: wahyuniar_pbsi@unmus.ac.id
}

\begin{abstract}
The purpose of this community service is to improve basic computer skills based on the Microsoft Office application for students of SMK Negeri 3 Merauke. This community service method used training with material presentation techniques and questions and answers. The training participants were 34 students of class X Multimedia Department. There were 2 (two) activities carried out, namely: the preparation of a Microsoft office training manual and a questionnaire response to training participants as well as the implementation of basic computer training activities online. The instruments used are response questionnaires and activity documentation. The results of this community service activity indicate that overall each indicator of the response of basic computer training participants is in the 'good' and 'very good' categories. The average percentage of responses is 98.23 which is included in the 'very good' category.
\end{abstract}

Abstrak: Tujuan pengabdian masyarakat ini adalah untuk meningkatkan kemampuan komputer dasar berbasis aplikasi Microsoft Offise bagi siswa SMK Negeri 3 Merauke. Metode pengabdian ini menggunakan pelatihan dengan teknik presentasi materi serta tanya jawab. Peserta pelatihan adalah siswa kelas X Jurusan Multimedia sebanyak 34 orang. Terdapat 2 (dua) kegiatan yang dilaksanakan, yakni: penyusunan buku panduan pelatihan Microsoft office dan angket respon peserta pelatihan serta pelaksanaan kegiatan pelatihan komputer dasar secara daring. Instrumen yang digunakan adalah angket respon dan dokumentasi kegiatan. Hasil kegiatan pengabdian ini menunjukkan bahwa secara keseluruhan tiap indikator respon peserta pelatihan komputer dasar dalam kategori 'baik' dan 'sangat baik'. Adapun rerata presentase respon adalah 98,23 yang masuk dalam kategori 'sangat baik'.

\section{Article History:}

Received: 22-08-2021

Reviewed: 20-09-2021

Accepted: 11-10-2021

Published: 13-11-2021

\section{Key Words:}

Training, Basic

Computer,

Microsoft Office.

Sejarah Artikel:

Diterima: 22-08-2021

Direview: 20-09-2021

Disetujui: 11-10-2021

Diterbitkan: 13-11-2021

\section{Kata Kunci:}

Pelatihan, Komputer

Dasar, Microsoft Office.

How to Cite: Wahyuniar, W., Sari, D., \& Uspayanti, R. (2021). Pelatihan Komputer Dasar Berbasis Aplikasi Microsoft Office bagi Siswa SMK Negeri 3 Merauke Provinsi Papua. Jurnal Pengabdian UNDIKMA, 2(2), 195202. doi:https://doi.org/10.33394/jpu.v2i2.4176

https://doi.org/10.33394/jpu.v2i2.4176

This is an open-access article under the CC-BY-SA License.

\section{Pendahuluan}

Teknologi Informasi dan Komunikasi (TIK) telah memberikan dampak yang luas terhadap seluruh sektor kehidupan. Sektor pendidikan pun tidak luput dari perkembangan TIK. Teknologi Informasi dan Komunikasi (TIK) telah memberikan kontribusi sangat kuat bagi perkembangan dinamika pendidikan (Juwariyah, 2021), baik dalam proses pembelajaran, informasi produksi ilmu pengetahuan, maupun pegelolaan administrasi di seluruh aspek. Saat ini dan pada masa yang akan datang, semua tingkatan pendidikan mulai menghadapi perkembangan dan perubahan global, ilmu pengetahuan, teknologi, seni dan budaya (Santika, 2021). Dengan pesatnya perkembangan teknologi saat ini, kebutuhan 
manusia semakin meningkat. Saat ini terdapat keterkaitan antara kemajuan teknologi dengan pertumbuhan kebutuhan manusia, yaitu kebutuhan manusia semakin mudah untuk dipenuhi (Zein, 2021).

Perkembangan teknologi saat ini khususnya di kalangan pelajar salah satunya bertujuan guna mengoptimalisasi pemanfaatan penggunaan software aplikasi yang mudah dan powerfull (Kelen et al., 2020) namun tetap mempermudah siswa-siswi untuk melakukan editing materi yang dibutuhkan (Febrilia \& Setyawati, 2020; R. Sari et al., 2020). Kemampuan dan kemahiran dalam TIK penting bagi semua orang serta orang-orang yang terlibat harus dapat berpartisipasi aktif dan terus meningkatkan daya saingnya (Abdul Latip, 2020; Eliana et al., 2016; Puspitarini et al., 2013). Pemanfaatan TIK dalam suatu kegiatan akan menjadikan kegiatan tersebut menjadi lebih cepat, mudah, dan efisien (Anshori, 2017; Dağhan, 2017; Surani, 2019). Oleh karena itu, penguasaan terhadap perangkat teknologi perlu diajarkan pada semua tingkatan.

Perkembangan teknologi informasi yang semakin pesat di era globalisasi saat ini tidak bisa dihindari lagi pengaruhnya terhadap dunia pendidikan (Bahri et al., 2020; P. A. C. Dinata et al., 2020; Pertiwi \& Sutama, 2020; Reski \& Sari, 2020; D. K. Sari et al., 2018). Tuntutan global menuntut dunia pendidikan untuk selalu dan senantiasa menyesuaikan perkembangan teknologi terhadap usaha dalam peningkatan mutu pendidikan (Pri Ariadi Cahya Dinata et al., 2020; D. K. Sari et al., 2020), terutama penyesuaian penggunaan teknologi informasi dan komunikasi bagi dunia pendidikan khususnya dalam proses pembelajaran (Budiman, 2017; R. Sari et al., 2020).

Kemampuan menggunakan dan memanfaatkan perangkat TIK menjadi salah satu faktor kunci agar sumber daya manusia Indonesia dapat bersaing dengan negara lain. Sejalan dengan Shopova (2004) yang menyatakan bahwa kompetensi dan tingkatan literasi TIK berpengaruh terhadap efektifitas dan efisiensi proses belajar mengajar. Sementara itu, literasi TIK yang lebih spesifik pada penggunaan media digital. Lebih lanjut, Zam (2021) menyebutkan bahwa literasi TIK dipengaruhi oleh tingkat generasi dan usia pengguna teknologi, generasi muda lebih mudah mengelola teknologi dibanding generasi orang tua. Penggunaan Microsoft Office (Word, Excel, dan Powerpoint) semakin meningkat dengan adanya wabah Covid-19 yang mengharuskan proses pembelajaran lebih banyak dilakukan secara online, yang salah satunya mengharuskan siswa/i mengerjakan tugas-tugas mereka menggunakan Microsoft Office (Kelen et al., 2020; Siahaan, 2012).

Berdasarkan hasil observasi pada siswa kelas X Jurusan Multimedia SMK Negeri 3 Merauke, tidak semua siswa memiliki pemahaman yang baik tentang penggunaan aplikasi komputer Microsoft Office. Hal tersebut dibuktikan dengan hasil wawancara guru yang menyatakan bahwa kemampuan pengoperasian Microsoft Office masih sangat kurang terlebih pada siswa kelas $\mathrm{X}$. Mengingat pentingnya kemampuan dalam mengoperasikan Microsoft Office ini bagi siswa, maka perlu diselenggarakan pelatihan daring, yakni Pelatihan Komputer Dasar Siswa Kelas X Jurusan Multimedia SMK Negeri 3 Merauke. Pelatihan ini diharapkan menjadi solusi untuk menghadapi perkembangan TIK serta siswa dapat menguasai keterampilan dasar komputer dalam hal ini Microsoft Office.

\section{Metode Pengabdian}

Kegiatan pengabdian ini dilaksanakan secara daring menggunakan aplikasi Google Meet selama 1 (satu) bulan. Metode pengabdian yang digunakan adalah ceramah dengan teknik presentasi materi komputer dasar, dilanjutkan dengan tanya jawab. Kegiatan ini dikemas dalam bentuk pelatihan. Peserta dalam kegiatan ini adalah siswa kelas X Jurusan 
Multimedia sebanyak 34 orang. Terdapat 2 (dua) kegiatan yang dilaksanakan, yakni: penyusunan buku panduan pelatihan Microsoft office sebagai pegangan instruktur dalam menyampaikan materi pelatihan komputer dasar dan angket respon peserta pelatihan serta Pelaksanaan kegiatan pelatihan komputer dasar secara daring. Instrumen yang digunakan untuk memperoleh data pengabdian ini yakni; angket respon dan dokumentasi kegiatan. Angket respon peserta diberikan sesaat setelah pelatihan komputer dasar. Adapun kisi-kisi angket respon dapat dilihat pada tabel berikut.

Tabel 1. Indikator Angket Respon Peserta

\begin{tabular}{|c|c|c|}
\hline No. & \multicolumn{2}{|c|}{ Indikator } \\
\hline 1. & \multicolumn{2}{|c|}{ Instruktur menyampaikan materi secara keseluruhan. } \\
\hline 2. & \multicolumn{2}{|c|}{ Instruktur menyampaikan materi secara berurutan. } \\
\hline 3. & \multicolumn{2}{|c|}{ Materi Pelatihan Komputer Dasar bermanfaat dalam membantu kegiatan be } \\
\hline 4. & \multicolumn{2}{|c|}{ Materi Pelatihan Komputer Dasar berhubungan dengan pembelajaran di sek } \\
\hline 5. & \multicolumn{2}{|c|}{ Peserta pelatihan memahami materi yang disampaikan instruktur. } \\
\hline 6. & \multicolumn{2}{|c|}{ Instruktur menyampaikan materi disertai dengan contoh. } \\
\hline 7. & \multicolumn{2}{|c|}{$\begin{array}{l}\text { Instruktur menggunakan media yang memudahkan peserta pelatihan untuk } \\
\text { memahami materi. }\end{array}$} \\
\hline 8. & \multicolumn{2}{|c|}{ Peserta pelatihan diberi kesempatan untuk menyampaikan gagasan atau pert } \\
\hline 9. & \multicolumn{2}{|c|}{ Instruktur menanggapi gagasan atau pertanyaan dari peserta pelatihan. } \\
\hline 10. & \multicolumn{2}{|c|}{ Instruktur dan peserta pelatihan saling berinteraksi dengan baik. } \\
\hline \multirow{2}{*}{\multicolumn{3}{|c|}{$\begin{array}{l}\text { Hasil persentase respon tersebut diubah menjadi data kualitatif dengan kriteria se } \\
\text { ditunjukkan pada Tabel } 2 \text {. } \\
\text { Tabel 2. Kriteria respon siswa terhadap Pelatihan Komputer Dasar }\end{array}$}} \\
\hline & & \\
\hline \multicolumn{3}{|c|}{ Tabel 2. Kriteria respon siswa terhadap Pelatihan Komputer Dasa } \\
\hline & $81,25<x<100$ & Sangat Baik \\
\hline & $62,5<x<81,25$ & \\
\hline & $43,75<x<62,5$ & Kurang Baik \\
\hline & & \\
\hline
\end{tabular}

\section{Hasil Pengabdian dan Pembahasan}

Kegiatan pengabdian ini dilaksanakan sebanyak 2 (dua) tahap, yakni: penyusunan buku panduan pelatihan Microsoft office sebagai pegangan instruktur dalam menyampaikan materi pelatihan komputer dasar dan angket respon peserta pelatihan.

\section{1) Penyusunan Buku Panduan Pelatihan Microsoft office}

Tahap awal kegiatan ini adalah penyusunan buku panduan pelatihan Microsoft Office sebagai pegangan instruktur dalam menyampaikan materi. Dalam buku panduan tersebut terdapat 3 (tiga) materi yang disampaikan oleh instruktur, yakni: materi Microsoft Word, materi Microsoft Excel, dan materi Microsoft Power Point. Materi pertama adalah Microsoft Word dengan sub materi: dasar-dasar Microsoft Word, bekerja dengan teks pada Microsoft Word, tata letak dan pencetakan, serta bekerja dengan objek pada Microsoft Word. Materi kedua adalah Microsoft Excel dengan sub materi: mengenal dasar-dasar Microsoft Excel, bekerja dengan sheet dan sel pada Microsoft Excel, formula dan fungsi pada Microsoft Excel, serta bekerja dengan data. Materi ketiga adalah Microsoft Power Point dengan sub materi: mengenal presentasi dengan menggunakan Microsoft Power 
Point, pengaturan slide pada Microsoft Power Point, menyisipkan objek, serta transisi dan animasi pada Microsoft Power Point.

Setelah menyusun buku panduan pelatihan, tahap berikut adalah menyusun/membuat angket respon peserta pelatihan dengan menggunakan Google Form. Pembuatan angket ini bertujuan untuk melihat respon peserta pelatihan terhadap materi pelatihan yang disajikan instruktur. Angket yang diberikan kepada peserta berupa 10 (sepuluh) indikator dengan pilihan tanggapan: sangat setuju, kurang setuju, dan tidak setuju.

\section{2) Pelaksanaan Kegiatan Pelatihan Komputer Dasar Secara Daring}

Pelatihan komputer dasar sebagai metode dalam memberikan informasi dan pengetahuan kepada mitra sebagai peserta yang terdiri dari siswa kelas X Jurusan Multimedia dengan jumlah 34 orang. Materi pelatihan terdiri atas 3 (tiga), yakni: Microsoft Word, Microsoft Excel, dan Microsoft Power Point. Kegiatan hari pertama dilaksanakan pada hari Rabu, 11 Agustus 2021. Kegiatan dimulai dengan pembukaan kegiatan oleh MC (Master of Ceremony) dilanjutkan pemaparan CV instruktur. Setelah itu, pemaparan materi pertama oleh instruktur yakni Microsoft Word. Dari materi tersebut, peserta pelatihan dapat mengenal perangkat keras, dasar-dasar Microsoft Word, bekerja dengan teks pada Microsoft Word, tata letak dan pencetakan, serta bekerja dengan objek pada Microsoft Word.

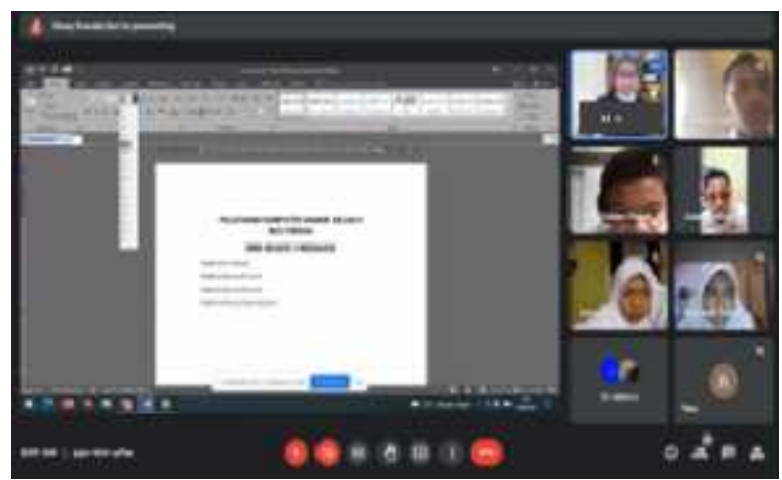

\section{Gambar 1. Presentasi Materi Microsoft Word}

Kegiatan hari kedua dilaksanakan pada hari Kamis, 12 Agustus 2021. Kegiatan dimulai dengan pemaparan CV instruktur oleh MC (Master of Ceremony). Setelah itu, pemaparan materi Microsoft Excel oleh instruktur. Dari materi tersebut, peserta pelatihan dapat mengenal dasar-dasar Microsoft Excel, bekerja dengan sheet dan sel, formula dan fungsi, serta bekerja dengan data.

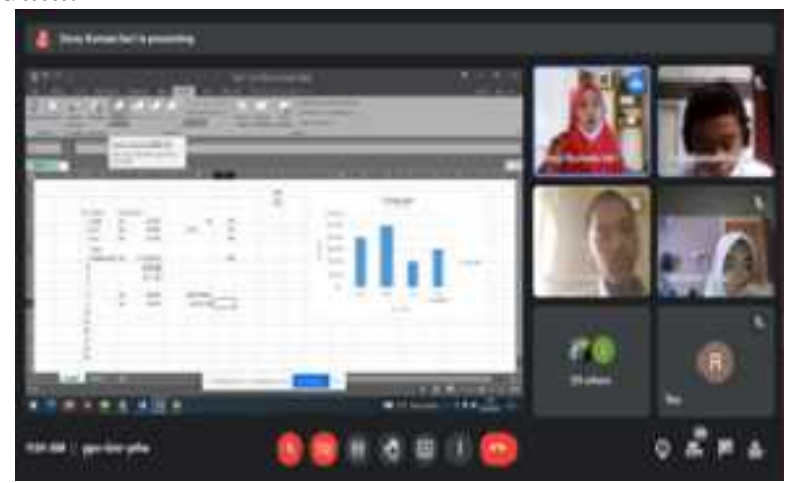

Gambar 2. Presentasi Materi Microsoft Excel 
Kegiatan kedua yakni pemaparan materi Microsoft Power Point oleh instruktur. Dari materi tersebut, peserta pelatihan dapat mengenal presentasi dengan menggunakan Microsoft Power Point, pengaturan slide, menyisipkan objek, serta transisi dan animasi. Kemudian, pada kegiatan ketiga yakni penutup, peserta diberi link untuk mengisi kuesioner terkait kegiatan pelatihan komputer dasar.

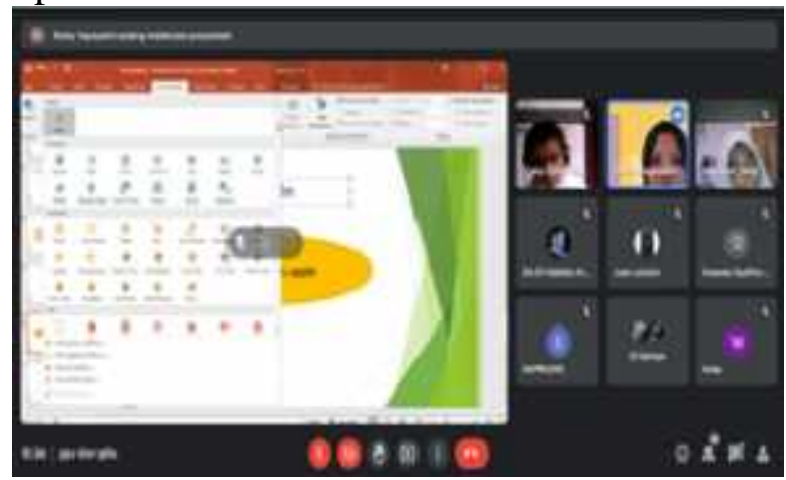

\section{Gambar 3. Presentasi Materi Microsoft Power Point}

Angket respon peserta diberikan sesaat setelah pelatihan. Angket respon peserta pelatihan terdiri atas 10 (sepuluh) indikator. Angket tersebut berupa angket peserta setelah mengikuti pelatihan komputer dasar. Data hasil respon peserta ditunjukkan pada Tabel 3.

\section{Tabel 3. Data Respon Peserta}

\begin{tabular}{|c|c|c|}
\hline No. & Indikator & Rerata Skor \\
\hline 1. & Instruktur menyampaikan materi secara keseluruhan. & 2,97 \\
\hline 2. & Instruktur menyampaikan materi secara berurutan. & 2,97 \\
\hline 3. & $\begin{array}{l}\text { Materi Pelatihan Komputer Dasar bermanfaat dalam } \\
\text { membantu kegiatan belajar di sekolah. }\end{array}$ & 3 \\
\hline 4. & $\begin{array}{l}\text { Materi Pelatihan Komputer Dasar berhubungan dengan } \\
\text { pembelajaran di sekolah. }\end{array}$ & 2,88 \\
\hline 5. & $\begin{array}{l}\text { Peserta pelatihan memahami materi yang disampaikan } \\
\text { instruktur. }\end{array}$ & 2,76 \\
\hline 6. & Instruktur menyampaikan materi disertai dengan contoh. & 2,97 \\
\hline 7. & $\begin{array}{l}\text { Instruktur menggunakan media yang memudahkan } \\
\text { peserta pelatihan untuk memahami materi. }\end{array}$ & 2,94 \\
\hline 8. & $\begin{array}{l}\text { Peserta pelatihan diberi kesempatan untuk } \\
\text { menyampaikan gagasan atau pertanyaan. }\end{array}$ & 3 \\
\hline 9. & $\begin{array}{l}\text { Instruktur menanggapi gagasan atau pertanyaan dari } \\
\text { peserta pelatihan. }\end{array}$ & 2,97 \\
\hline 10. & $\begin{array}{l}\text { Instruktur dan peserta pelatihan saling berinteraksi } \\
\text { dengan baik. }\end{array}$ & 3 \\
\hline & Rerata Presentase Respon & 98,23 \\
\hline
\end{tabular}

Berdasarkan tabel di atas, indikator pertama rerata skor adalah 2,97; indikator kedua rerata skor adalah 2,97; indikator ketiga rerata skor adalah 3; indikator keempat rerata skor adalah 2,88; indikator kelima rerata skor adalah 2,76; indikator keenam rerata skor adalah 2,97; indikator ketujuh rerata skor adalah 2,94; indikator kedelapan rerata skor adalah 3; indikator kesembilan rerata skor adalah 2,97; dan indikator kesepuluh rerata skor adalah 3. Secara keseluruhan, tiap indikator respon peserta pelatihan komputer dasar dalam kategori 'baik' dan 'sangat baik'. Adapun rerata presentase respon adalah 98,23 yang masuk dalam kategori 'sangat baik'. Hasil angket respon peserta dapat dilihat pada Gambar 4. 


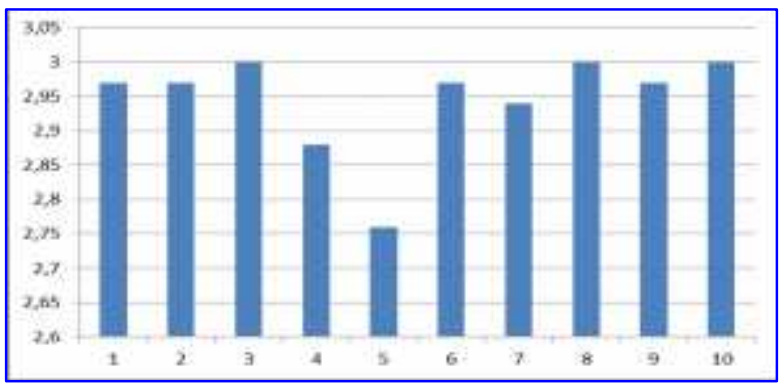

Gambar 4. Respon Peserta

Merujuk pada hasil presentase respon peserta yang termasuk dalam kategori 'baik dan 'sangat baik', rencana tindak lanjut dari kegiatan pengabdian ini adalah pemberian tugas. Pemberian tugas dalam bentuk portofolio untuk tiap materi yang telah dipaparkan oleh pemateri. Pemberian tugas dimaksudkan untuk melihat pemahaman siswa dalam pengoperasian Microsoft Office sekaligus sebagai bahan evaluasi bagi tim PKM.

\section{Kesimpulan}

Berdasarkan kegiatan pengabdian ini, dapat disimpulkan bahwa kegiatan ini telah memberikan respon terhadap permasalahan mitra. Adapun permasalahan mitra, yakni: tidak semua siswa memiliki pemahaman yang baik tentang penggunaan aplikasi komputer Microsoft Office. Secara keseluruhan, tiap indikator respon peserta pelatihan komputer dasar dalam kategori 'baik' dan 'sangat baik'. Adapun rerata presentase respon adalah 98,23 yang masuk dalam kategori 'sangat baik'.

\section{Saran}

Saran dalam kegiatan ini adalah perlu kerja sama dan tindak lanjut antara guru dan tim PKM dalam penguatan materi yang telah disajikan. Materi pelatihan dikembangkan sesuai dengan kebutuhan guru dalam melaksanakan pembelajaran di dalam kelas maupun di luar kelas. Selain itu, materi pelatihan juga diharapkan bisa menjadi penunjang siswa pada era 4.0 saat ini.

\section{Daftar Pustaka}

Abdul Latip. (2020). Peran Literasi Teknologi Informasi Dan Komunikasi Pada Pembelajaran Jarak Jauh Di Masa Pandemi Covid-19. EduTeach: Jurnal Edukasi Dan Teknologi Pembelajaran, 1(2), 108-116. https://doi.org/10.37859/eduteach.v1i2.1956

Akbar, S. (2013). Instrumen Perangkat Pembelajaran. Rosdakarya.

Anshori, S. (2017). Pemanfaatan TIK sebagai Sumber dan Media Pembelajaran di Sekolah. Jurnal Ilmu Pendidikan PKn Dan Sosial Budaya, 3(3), 10-20. file:///C:/Users/WINDOWS 10/Downloads/Documents/61-Article Text-540-1-1020191223.pdf

Bahri, S., Rahayu, M., Sari, D. K., \& Simbolon, M. (2020). Analysis of information and communication technology literacy capabilities to the high school physics teacher in Merauke. Gravity: Jurnal Ilmiah Penelitian Dan Pembelajaran Fisika, 6(1), 47-53. https://doi.org/10.30870/gravity.v6i1.6365

Budiman, H. (2017). Peran teknologi informasi dan komunikasi dalam pendidikan. Tadzkiyyah: Jurnal Pendidikan Islam, 8(2), 75-83. 
Dağhan, G. (2017). Views of students about technology, effects of technology on daily living and their professional preferences. Turkish Online Journal of Educational Technology, 16(4), 187-194.

Dinata, P. A. C., Suparwoto, S., \& Sari, D. K. (2020). Problem-based online learning assissted by whatsapp to facilitate the scientific learning of 2013 Curriculum. Berkala Ilmiah Pendidikan Fisika, 8(1), 1-11. https://doi.org/10.20527/bipf.v8i1.7647

Dinata, Pri Ariadi Cahya, Sakman, S., \& Syarpin, S. (2020). Pelatihan Blended Learning Berbantuan Webex Meeting dan Mentimeter untuk Mengefektifkan Kegiatan Belajar Mengajar. Bubungan Tinggi: Jurnal Pengabdian Masyarakat, 2(2), 64. https://doi.org/10.20527/btjpm.v2i2.2146

Eliana, E. D. S., Senam, Wilujeng, I., \& Jumadi. (2016). The effectiveness of project-based elearning to improve ICT literacy. Jurnal Pendidikan IPA Indonesia, 5(1), 51-55. https://doi.org/10.15294/jpii.v5i1.5789

Febrilia, B. R. A., \& Setyawati, D. U. (2020). Pelatihan Microsoft Excel Bagi Mahasiswa Calon Guru Universitas Pendidikan Mandalika. Jurdimas (Jurnal Pengabdian Kepada Masyarakat) Royal, 3(2), 181-186. https://doi.org/10.33330/jurdimas.v3i2.619

Juwariyah, I. (2021). Implementasi merdeka belajar dalam pembelajaran daring selama pandemi COVID-19. In A. Wijayanto, A. S. Anggaira, W. I. Bayu, \& F. Amiq (Eds.), Implementasi dan Problematika Merdeka Belajar (Vol. 6, Issue 11, pp. 951-952). Akademia Pustaka.

Kelen, Y. P., Rema, Y. O., Kolloh, R. Y., Naat, V., Benolon, E. M., \& Nule, S. Y. (2020). Pelatihan Penggunaan Microsoft Office Bagi Siswa SMPS St. Yosef Maubesi. JATI EMAS (Jurnal Aplikasi Teknik Dan Pengabdian Masyarakat), 4(2), 85. https://doi.org/10.36339/je.v4i2.330

Pertiwi, R., \& Sutama, S. (2020). Membudayakan Kelas Digital Untuk Membimbing Siswa dalam Pembelajaran di Tengah Pandemi Covid-19. JKTP: Jurnal Kajian Teknologi Pendidikan, 3(4), 350-365. https://doi.org/10.17977/um038v3i42020p350

Puspitarini, E. W., Sunaryo, S., \& Suryani, E. (2013). Pemodelan Technological Pedagogical Content Knowledge ( TPACK ) Berbasis Teknologi Informasi Dan Komunikasi ( TIK ) Dengan Pendekatan Structural Equation Modeling ( SEM ). Seminar Nasional Manajemen Teknologi XVIII, 1-8.

Reski, A., \& Sari, D. K. (2020). Analisis Kemampuan TPACK Guru Fisika Se-Distrik Merauke. Jurnal Kreatif Online, 8(1), 1-8.

Santika, I. G. N. (2021). Grand Desain Kebijakan Strategis Pemerintah Dalam Bidang Pendidikan Untuk Menghadapi Revolusi Industri 4.0. Jurnal Education and Development, 9(2), 369-377.

Sari, D. K., Bahri, S., Simbolon, M., Nikat, R. F., \& Dinata, P. A. C. (2020). Pembelajaran Daring Berbantuan Whatsapp Pada Matakuliah Metodologi Penelitian Pendidikan Fisika. Musamus Journal of Science Education, 3(1).

Sari, D. K., Supahar, \& Ralmugiz, U. (2018). The influence of android-based isomorphic physics (Forfis) application on analogical transfer and self-diagnosis skill of students at SMA Negeri 3 Kupang. Jurnal Pendidikan IPA Indonesia, 7(2), 154-161. https://doi.org/10.15294/jpii.v7i2.14268

Sari, R., Fitriyani, A., \& Prabandari, R. D. (2020). Optimalisasi Penggunaan MS. Word dan MS. Excel Pada Siswa SMP PGRI Astra Insani Bekasi. Jurnal Pengabdian Kepada Masyarakat UBJ, 3(2), 95-104. https://doi.org/10.31599/jabdimas.v3i2.184 
Siahaan, S. M. (2012). Penggunaan Teknologi Informasi dan Komunikasi dalam Pembelajaran Fisika. Energi, Lingkungan, Dan Teknologi Masa Depan: Tantangan Dan Peluang Ilmu Fisika, 13-20.

Surani, D. (2019). Studi Literatur: Peran Teknologi Pendidikan dalam Pendidikan 4.0. Seminar Nasional Pendidikan FKIP, 2(1), 456-469.

T Shopova. (2004). Digital literacy of student and its improvement at the university. Journal of Efficiency and Responsibility in Education and Science, 7(2).

Zam, E. M. (2021). Peran literasi tekonologi informasi dan komunikasi pada pembelajaran jarak jauh di masa pandemi COVID-19. EDUTECH: Jurnal Inovasi Pendidikan Berbantuan Teknologi, 1(1). 